\title{
Quantitation of Four Guanine Oxidation Products from Reaction of DNA with Varying Doses of Peroxynitrite
}

\author{
Hongbin Yua , Lata Venkatarangan ${ }^{\mathrm{a}}$, John S. Wishnok ${ }^{\mathrm{a}}$, and Steven R. Tannenbaum ${ }^{\mathrm{a}, \mathrm{b},{ }^{*}}$ \\ a Biological Engineering Division, Massachusetts Institute of Technology 77 Massachusetts Avenue, Room \\ 56-731A Cambridge, Massachusetts 02139 \\ b Department of Chemistry, Massachusetts Institute of Technology 77 Massachusetts Avenue, Room 56-731A \\ Cambridge, Massachusetts 02139
}

\section{Abstract}

The oxidation products obtained from the reaction of peroxynitrite $\left(\mathrm{ONOO}^{-}\right)$with $\mathrm{dG}$ include among others - 8-oxo-7,8-dihydro-2'-deoxyguanosine (8-oxodG), 2,2-diamino-4[(2-deoxy- $\beta$-Derythro-pentafuranosyl)amino]-5(2H)-oxazolone (oxazolone), spiroiminodihydantoin and $\mathrm{N}^{1}$-( $\beta$-Derythro-pentofuranosyl)-5-guanidinohydantoin (guanidinohydantoin). In the present work, the formation of these products from the treatment of calf thymus DNA with varying amounts of $\mathrm{ONOO}^{-}$was studied quantitatively in vitro. ${ }^{13} \mathrm{C}$-, ${ }^{15} \mathrm{~N}$-labeled standards were synthesized for the nucleosides of interest, and calf thymus DNA was reacted with $\mathrm{ONOO}^{-}$and digested enzymatically down to the nucleoside level. Specific modifications in the DNA were measured by HPLC separation followed by electrospray ionization tandem mass spectrometric analysis in the selected reactionmonitoring mode. Artifacts of the above four oxidation products, arising from oxidation of dG and/ or 8-oxodG during DNA digestion and subsequent work-up, were evaluated with $7-{ }^{15} \mathrm{~N}-\mathrm{dG}$ and/or stable-isotope labeled 8-oxodG as internal standards. Levels of artifactual 8-oxodG were about $5 / 10^{6}$ nucleosides. The artifacts of spiroiminodihydantoin and guanidinohydantoin, arising from 8oxodG, were $3.7 \%$ and $0.6 \%$ of the measured 8-oxodG values, respectively. No artifacts of oxazolone were detected. 8-OxodG and oxazolone were formed dose-dependently in DNA treated with $\mathrm{ONOO}^{-}$, while the levels of spiroiminodihydantoin and guanidinohydantoin increased significantly at low $\mathrm{ONOO}^{-}$doses, and then dropped off at higher $\mathrm{ONOO}^{-}$doses. The complexity of these doseresponse relationships is likely due to the dual role of peroxynitrite as both an oxidant and a nucleophile in competition with water.

\section{Keywords}

8-oxodG; oxazolone; spiroiminodihydantoin; guanidinohydantoin; peroxynitrite; calf thymus DNA

\section{Introduction}

Peroxynitrite $\left(\mathrm{ONOO}^{-}\right)$is a powerful oxidizing agent formed by the diffusion-controlled reaction of nitric oxide with superoxide $(1,2)$. Inflammatory cells such as neutrophils and macrophages, which are capable of simultaneously producing nitric oxide and superoxide, can therefore generate $\mathrm{ONOO}^{-}$in vivo. In chronic inflammatory states, these cells can overproduce $\mathrm{ONOO}^{-}$over prolonged periods of time, and excess $\mathrm{ONOO}^{-}$formation has been implicated in a number of pathological conditions such as rheumatoid arthritis and neurodegenerative

* Address correspondence to SRT: Massachusetts Institute of Technology, 77 Massachusetts Avenue, Room 56-731A, Cambridge, Massachusetts 02139. Telephone: (617)253-3792, fax: (617)252-1787, E-mail: srt@mit.edu. 
diseases (2-4) as well as in increased cancer risk (5). In addition to reacting with a number of cellular substrates, $\mathrm{ONOO}^{-}$reacts with DNA, resulting in both sugar (6-8) and nucleobase damage. Of the four DNA bases, guanine, with the lowest oxidation potential, is the most reactive (9-11). Major oxidation products arising from the reaction of $\mathrm{dG}$ with $\mathrm{ONOO}^{-}$include 8-oxodG (12-14) oxazolone, and its precursor, imidazolone (15,16) (Scheme 1). In addition, 8 -oxodG is at least 1000 times more reactive toward $\mathrm{ONOO}^{-}$than is $\mathrm{dG}(17)$, resulting in the formation of secondary oxidation products such as oxazolone (18), spiroiminodihydantoin (13), and guanidinohydantoin(19) (Scheme 1). These four DNA oxidation products are all promutagenic. 8-OxodG is a well-known DNA oxidation product, and has been shown to cause $\mathrm{G} \rightarrow \mathrm{T}$ transversions in both prokaryotic and eukaryotic cells (20-22). The mutagenic potential of oxazolone following DNA synthesis in vitro suggests that the formation of oxazolone in DNA mainly leads to $\mathrm{G} \rightarrow \mathrm{T}$ and to some extent $\mathrm{G} \rightarrow \mathrm{C}$ transversions (23). The replication of oxazolone-containing DNA in $E$. coli, also predominantly produces $\mathrm{G} \rightarrow \mathrm{T}$ transversions (24) and oxazolone has also been shown to constitute a blocking lesion during DNA synthesis (23) in vitro. The frequencies of the $\mathrm{G} \rightarrow \mathrm{T}$ transversions for oxazolone were found to be notably high (95\%) in comparison to the low mutation frequency (7\%) of 8-oxodG (24). Both diastereoisomers of spiroiminodihydantoin have been shown to be strong inhibitors of DNA polymerase extension in E.coli cells, causing a mixture of $\mathrm{G} \rightarrow \mathrm{T}$ and $\mathrm{G} \rightarrow \mathrm{C}$ transversions (24). The mutation frequency for spiroiminodihydantoin is at least an order of magnitude higher than that for 8-oxodG (25). Guanidinohydantoin is also a highly mutagenic lesion and causes exclusive $\mathrm{G} \rightarrow \mathrm{C}$ transversions (25). To assess the formation profile of these highly mutagenic lesions in vitro, the current work focused on the qualitative as well as quantitative formation of 8-oxodG, oxazolone, guanidinohydantoin, and spiroiminodihydantoin in calf thymus DNA treated with $\mathrm{ONOO}^{-}$(bolus), and we now report quantitation, by isotope-dilution-HPLCtandem mass spectrometry, of these modifications.

\section{Materials and methods}

The uniformly ${ }^{13} \mathrm{C},{ }^{15} \mathrm{~N}$ labeled dGTP $\left({ }^{13} \mathrm{C}\right.$ and $\left.{ }^{15} \mathrm{~N}>98 \%\right)$ was obtained from Cambridge Isotope Laboratories (Andover, MA). The syntheses of $1,2,7-{ }^{15} \mathrm{~N}_{3}-8$-oxodG and 3,7,8- ${ }^{15} \mathrm{~N}_{3^{-}}$ $\mathrm{N}^{1}$-(-D-erythro-pentofuranosyl)-5-guanidinohydantoin have been reported (26). NAP-10 DNA desalting columns were purchased from Amersham Pharmacia Biotech (Piscataway, NJ). Nuclease P1 and white-potato acid phosphatase were obtained from Calbiochem (San Diego, CA). Snake-venom phosphodiesterase (type I), bovine spleen phosphodiesterase (type II), alkaline phosphatase and calf thymus DNA were from Sigma (St. Louis, MO). Stock solutions of $\mathrm{ONOO}^{-}$were prepared from ozone and sodium azide as described earlier (27) and stored at $-80{ }^{\circ} \mathrm{C}$ until needed. $7-{ }^{15} \mathrm{~N}-\mathrm{dG}$ was a generous gift from Dr. T. M. Harris of Vanderbilt University. Microcon YM-10 centrifugal columns were purchased from Millipore (Bedford, MA). All other chemicals, reagents and solvents were purchased from Sigma-Aldrich, EM Science and other chemical distributors. UV/Vis measurements were made on an HP8452 diode-array spectrophotometer (Agilent Technologies, Palo Alto, CA). HPLC analyses were carried out on an Agilent 1100 Series HPLC system with binary pumps, a degasser, an autoinjectorand a diode array detector. Quantitative LC-MS/MS analyses were conducted on an Agilent 1100 HPLC pump system interfaced with an Sciex API 3000 tandem quadrupole mass spectrometer (Applied Biosystems, Framingham, MA). ESI-MS experiments for recoveries, isotopic purities, and structure confirmations were done on an Agilent (Palo Alto, CA) MSDTOF.

\section{Synthesis of labeled standards}

$1 .{ }^{13} \mathrm{C},{ }^{15} \mathrm{~N}$ labeled dG-The uniformly ${ }^{13} \mathrm{C},{ }^{15} \mathrm{~N}$ labeled dGTP $(0.5 \mathrm{mg})$ was dissolved in water and incubated with 1 unit of alkaline phosphatase (in a $10 \times$ alkaline phosphatase buffer) at $37^{\circ} \mathrm{C}$ for $2 \mathrm{~h}$. The enzyme was removed by centrifugation on a Microcon YM-10 column. 
Conversion of the labeled dGTP to the corresponding labeled dG was complete. The labeled $\mathrm{dG}$ was purified by HPLC using a $250 \times 2.1 \mathrm{~mm}, 5 \mu \mathrm{m}$ Supelcosil LC-18-DB column (Supelco, Bellafonte, PA). The mobile phase consisted of $50 \mathrm{mM}$ ammonium acetate (A) and acetonitrile (B) with a gradient of $0-32 \%$ B over $40 \mathrm{~min}$ at a flow rate of $0.25 \mathrm{~mL} / \mathrm{min}$ (dG retention time 14.0 min).

2. ${ }^{13} \mathrm{C},{ }^{15} \mathrm{~N}$ labeled 8-oxodG- ${ }^{13} \mathrm{C},{ }^{15} \mathrm{~N}$ labeled 8-oxodG was synthesized from the uniformly ${ }^{13} \mathrm{C},{ }^{15} \mathrm{~N}$ labeled dG as described by Kasai and Nishimura (28). Labeled 8-oxodG was formed as a minor product and purified by HPLC using a $250 \times 4.6 \mathrm{~mm}, 5 \mu \mathrm{m}$ Columbus C18 column (Phenomenex, Torrance, CA). The mobile phase described above was delivered as a gradient of $0-20 \% \mathrm{~B}$ over $40 \mathrm{~min}$ at a flow rate of $1 \mathrm{~mL} / \mathrm{min}$ (retention times: labeled dG, $18.0 \mathrm{~min}$, labeled 8-oxodG, $19.6 \mathrm{~min}$, see supporting information Figure 1; ESI-MS of labeled 8-oxodG: $m / z 299.0[\mathrm{M}+\mathrm{H}]^{+}$and $m / z 177.9[\mathrm{BH}+\mathrm{H}]^{+}$, see supporting information Figure 2).

3. ${ }^{13} \mathrm{C},{ }^{15} \mathrm{~N}$ labeled oxazolone-A mixture of the labeled $\mathrm{dG}(500 \mu \mathrm{M})$ and riboflavin $(100$ $\mu \mathrm{M}$ ) in water was irradiated with visible light for $40 \mathrm{~min}$ (29). The reaction mixture was purified by HPLC using a $250 \times 4.6 \mathrm{~mm}, 5 \mu \mathrm{m}$ Synergi Hydro RP column (Phenomenex, Torrance, CA) with UV detection wavelengths at $230 \mathrm{~nm}$ and $320 \mathrm{~nm}$. The mobile phase was water (A) and acetonitrile (B) with a gradient of $100 \%$ A for the first 15 min and then a ramp to $30 \% \mathrm{~B}$ over $10 \mathrm{~min}$ at a flow rate of $1.0 \mathrm{~mL} / \mathrm{min}$ (imidazolone retention time $12.7 \mathrm{~min}$ ). The fraction eluting between 12 and $13 \mathrm{~min}$ was collected and incubated at $37{ }^{\circ} \mathrm{C}$ overnight to form oxazolone (see supporting information Figure 3). The resulting solution was freeze-dried to give labeled oxazolone (ESI-MS: $m / z 259.1\left[\mathrm{M}+\mathrm{H}^{+}\right]^{+}, m / z 214.0\left[\mathrm{M}+\mathrm{H}^{+}-\mathrm{CO}_{2}\right]^{+}, 138.0[\mathrm{BH}$ $\left.+\mathrm{H}^{+}\right]^{+}, 122.1\left[\mathrm{M}+\mathrm{H}^{+}-137\right]^{+}$, see supporting information Figure 4).

4. ${ }^{13} \mathrm{C},{ }^{15} \mathrm{~N}$ labeled spiroiminodihydantoin-Irradiation of an aerated $\mathrm{D}_{2} \mathrm{O}$ solution of the uniformly ${ }^{13} \mathrm{C},{ }^{15} \mathrm{~N}$ labeled $\mathrm{dG}(200 \mu \mathrm{M})$ and methylene blue $(100 \mu \mathrm{M})$ with visible light for $4 \mathrm{~h}$ resulted in the formation of the corresponding spiroiminodihydantoin $(13,30,31)$. The reaction mixture was purified by HPLC using a $50 \times 2.0 \mathrm{~mm}, 5 \mu \mathrm{m}$, Luna amino column (Phenomenex, Torrance, CA). The mobile phase was $50 \mathrm{mM}$ ammonium acetate (A) and acetonitrile (B) delivered isocratically $(75 \% \mathrm{~B}$ and $25 \% \mathrm{~A}$ ) at $0.2 \mathrm{~mL} / \mathrm{min}$ (two

diastereoisomers of spiroiminodihydantoin retention times at 20.0 and $23.0 \mathrm{~min}$, see supporting information Figure 5; ESI-MS: $m / z, 315.1\left[\mathrm{M}+\mathrm{H}^{+}\right]^{+}, m / z$ 194.0 $\left[\mathrm{BH}+\mathrm{H}^{+}\right]^{+}, m / z, 122.1[\mathrm{M}$ $\left.+\mathrm{H}^{+}-193\right]^{+}$, see supporting information Figure 6).

\section{Molar extinction coefficients for spiroiminodihydantoin and oxazolone}

${ }^{3} \mathrm{H}-\mathrm{dG}$ was used as the starting material for the syntheses of ${ }^{3} \mathrm{H}$-oxazolone and ${ }^{3} \mathrm{H}$ spiroiminodihyantoin according to procedures described above. The specific activity of $\mathrm{dG}$ was determined by scintillation counting $(0.77 \mathrm{mCi} / \mathrm{mmol})$, and purified ${ }^{3} \mathrm{H}$-oxazolone and ${ }^{3} \mathrm{H}$-spiroiminodihyantoin were used for determination of the molar extinction coefficients.

\section{Reaction of Calf Thymus DNA with ONOO-}

Concentrations of the $\mathrm{ONOO}^{-}$stock solutions were determined for serial dilutions with $0.1 \mathrm{~N}$ $\mathrm{NaOH}$ by measuring the absorbance at $\lambda=302 \mathrm{~nm}\left(\varepsilon=1670 \mathrm{M}^{-1} \mathrm{~cm}^{-1}\right)$ (32). Calf thymus DNA $(2230 \mu \mathrm{g})$ was dissolved in $1900 \mu \mathrm{L}$ of potassium phosphate $(150 \mathrm{mM})$ and sodium bicarbonate $(25 \mathrm{mM})(\mathrm{pH} 7.2)$. The guanine content in this solution was calculated to be $1100 \mu \mathrm{M}$. The solution was divided into aliquots $(100 \mu \mathrm{L})$ and each aliquot was diluted to 400 $\mu \mathrm{L}$ with potassium phosphate/sodium bicarbonate buffer (guanine content $\sim 275 \mu \mathrm{M}$ ). Varying amounts of the $\mathrm{ONOO}^{-}$stock solution were added to the buffered DNA solution followed by rapid vortexing for $1 \mathrm{~min}$. The samples were left at room temperature for 1 hour and then desalted by passing through NAP-10 columns. Recovery of the DNA was over $90 \%$ as determined by UV/Vis spectroscopy. In control experiments, calf thymus DNA treated with a 
deactivated $\mathrm{ONOO}^{-}$solution was assayed under the same conditions to determine the basal levels of the four nucleosides of interest. The treatment of calf thymus DNA with $\mathrm{ONOO}^{-}$at each dose was carried out in duplicate.

\section{Enzymatic digestion of calf thymus DNA and HPLC purification of 8-oxodG, spiroiminodihydantoin, guanidinohydantoin and oxazolone}

The protocols for enzymatic digestion of calf thymus DNA prior to analysis for 8-oxodG, spiroiminodihydantoin, and guanidinohydantoin, were similar except that the metal chelator desferrioxamine was added $(0.1 \mathrm{mM})$ to the digestion buffer in the analysis of 8-oxodG in order to minimize artifactual formation of that analyte. Typically, calf thymus DNA (117 $\mu \mathrm{g})$ was digested by incubation with 10 units of nuclease $\mathrm{P} 1$ in a mixture of $150 \mu \mathrm{L}$ of $\mathrm{H}_{2} \mathrm{O}, 25 \mu \mathrm{L}$ of $\mathrm{NaOAc}(1 \mathrm{M}, \mathrm{pH} 5.1)$, and $20 \mu \mathrm{L}$ of $\mathrm{ZnCl}_{2}(2 \mathrm{mM})$. A known amount of ${ }^{13} \mathrm{C},{ }^{15} \mathrm{~N}$ labeled 8oxodG, spiroiminodihydantoin, or $3,7,8-{ }^{15} \mathrm{~N}_{3}$-5-guanidinohydantoin was added to each DNA sample before the digestion. The samples were incubated at $37^{\circ} \mathrm{C}$ overnight followed by the addition of $25 \mu \mathrm{L}$ of sodium carbonate buffer ( $1 \mathrm{M}, \mathrm{pH}$ 9.2), snake venom phosphodiesterase (0.02 units), and alkaline phosphatase (4 units). The resulting mixture was incubated for $7 \mathrm{~h}$ at $37^{\circ} \mathrm{C}$. Since oxazolone is base-labile, the enzymatic digestion of DNA for the analysis of this compound was carried out under acidic conditions. Typically, calf thymus DNA (117 $\mu \mathrm{g})$ was digested by incubation with 10 units of nuclease P1 and 1 unit of white-potato acid phosphatase in a mixture of $150 \mu \mathrm{L}$ of $\mathrm{H}_{2} \mathrm{O}, 65 \mu \mathrm{L}$ of $\mathrm{NaOAc}(1 \mathrm{M}$, pH 5.1), and $50 \mu \mathrm{L}$ of $\mathrm{ZnCl}_{2}(2 \mathrm{mM})$. A known amount of ${ }^{13} \mathrm{C},{ }^{15} \mathrm{~N}$ labeled oxazolone was added to each DNA sample before the digestion. After incubation at $37^{\circ} \mathrm{C}$ overnight, the enzymes in the digestion mixture were removed with Microcon YM-10 centrifugal columns. The filtrate was then concentrated by freeze-drying. DNA oxidation products typically require some prepurification and concentration in order to maximize sensitivity and minimize the likelihood of coeluting interferences. Purification of 8-oxodG was performed using a $50 \times 2.1 \mathrm{~mm}, 5 \mu \mathrm{m}$ Zorbax Eclipse XDB-C18 column (Agilent Technologies, Palo Alto, CA). The mobile phase was 50 $\mathrm{mM}$ ammonium acetate (A) and acetonitrile (B) with a gradient of $0-15 \%$ B over $40 \mathrm{~min}$ at a flow rate of $0.2 \mathrm{~mL} / \mathrm{min}$ ( 8 -oxodG retention time at $7.0 \mathrm{~min}$; see supporting information Figure 7). Purification of spiroiminodihydantoin was performed using a $50 \times 2.0 \mathrm{~mm}, 5 \mu \mathrm{m}$, Lunaamino column (Phenomenex, Torrance, $\mathrm{CA}$ ). The mobile phase was $50 \mathrm{mM}$ ammonium acetate (A) and acetonitrile (B) as an isocratic mixture of $75 \% \mathrm{~B}$ and $25 \%$ A at $0.2 \mathrm{~mL} / \mathrm{min}$ (spiroiminodihydantoin retention time at 20.4 and $23.2 \mathrm{~min}$, see supporting information Figure 8). Guanidinohydantoin was prepurified using a $4.6 \times 250 \mathrm{~mm}, 5 \mu \mathrm{M}$ Zorbax Eclipse XDB C18 column with $100 \% 0.1 \%$ TFA in water at a flow rate of $0.4 \mathrm{~mL} / \mathrm{min}$. The HPLC fractions containing guanidinohydantoin were concentrated and further purified on a ThermosilKeystone $3.0 \times 100 \mathrm{~mm}, 5 \mu \mathrm{M}$ Hypercarb column (Phenomenex, Torrance, CA), with $0.1 \%$ TFA in water (A) and acetonitrile (B) delivered as a gradient of $0-9 \%$ B over $15 \mathrm{~min}$ at 0.4 $\mathrm{mL} / \mathrm{min}$. Oxazolone was purified on a Thermosil-Keystone Hypercarb column $(100 \times 2.1 \mathrm{~mm}$, $3 \mu \mathrm{m}$ ) using water (A) and acetonitrile (B) as a gradient of $0-30 \%$ B over 45 min at a flow rate of $0.2 \mathrm{~mL} / \mathrm{min}$ (oxazolone retention time at $14.8 \mathrm{~min}$, see supporting information Figure 9). The HPLC fractions containing 8-oxodG, spiroiminodihydantoin, guanidinohydantoin or oxazolone were collected and concentrated by freeze-drying.

\section{Artifacts of 8-oxodG formed by oxidation of dG during DNA digestion and work-up}

Untreated calf thymus DNA ( $145.6 \mu \mathrm{g})$ was digested as described above in the presence of 75 nmol of $7-{ }^{15} \mathrm{~N}-\mathrm{dG}$ and 62.4 pmol of $1,2,7-{ }^{15} \mathrm{~N}_{3}-8$-oxodG as internal standards along with desferrioxamine $(0.1 \mathrm{mM})$. 8-OxodG was purified by HPLC on a $4.6 \times 250 \mathrm{~mm}, 5 \mu \mathrm{m}$ Zorbax XDB-C18 column. The mobile phase consisted of water (A) and acetonitrile (B); 0-7\% B over $28 \mathrm{~min}$ at a flow of $0.8 \mathrm{~mL} / \mathrm{min}$. Fractions containing 8-oxodG (between 23.8 and $25.4 \mathrm{~min}$ ) and dG/7- $-{ }^{15} \mathrm{~N}-\mathrm{dG}$ (between 20.6 and $22 \mathrm{~min}$ ) were collected and concentrated. 


\section{Artifacts of spiroiminodihydantoin, guanidinohydantoin, and oxazolone from oxidation of 8- OxodG during DNA digestion and work-up}

Untreated calf thymus DNA $(145.6 \mu \mathrm{g})$ was digested as described above in the presence of desferrioxamine $(0.1 \mathrm{mM})$, and $7-{ }^{15} \mathrm{~N}-\mathrm{dG}(75 \mathrm{nmol})$. In measuring the artifacts of spiroiminodihydantoin and oxazolone, 62.4 pmol of $1,2,7-{ }^{15} \mathrm{~N}_{3}-8$-oxodG and $126.5 \mathrm{pmol}$ of the uniformly ${ }^{13} \mathrm{C},{ }^{15} \mathrm{~N}$ labeled spiroiminodihydantoin or 62.4 pmol of $1,2,7-15{ }^{13} \mathrm{C},{ }^{15} \mathrm{~N}$ labeled oxazolone were $\mathrm{N}_{3}-8$-oxodG and 86.4 pmol of the uniformly added to DNA before the digestion. For guanidinohydantoin, 62.4 pmol of the uniformly ${ }^{13} \mathrm{C},{ }^{15} \mathrm{~N}$ labeled 8-oxodG and 40.2 pmol of $3,7,8-{ }^{15} \mathrm{~N}_{3}-5$-guanidinohydantoin were added to DNA before the digestion. Purification of 8 -oxodG and dG/7- ${ }^{15} \mathrm{~N}-\mathrm{dG}$ from the digestion mixture was accomplished as described above. The HPLC fraction between 0-6 min on the $4.6 \times 250 \mathrm{~mm}, 5 \mu \mathrm{m}$ Zorbax XDB C18 column was collected for spiroiminodihydantoin, guanidinohydantoin, or oxazolone and freeze-dried. This fraction was further purified on a $3.0 \times 150 \mathrm{~mm}, 5 \mu \mathrm{m}$ Thermo-Keystone Hypercarb column; ammonium acetate (10 mM, pH 7.0: A) and acetonitrile (B) delivered from $0-18.7 \%$ B over $28 \mathrm{~min}$ at $0.2 \mathrm{~mL} / \mathrm{min}$. Fractions containing spiroiminodihydantoin (retention times of 14 and $16 \mathrm{~min}$ ), guanidinohydantoin (retention time at $18 \mathrm{~min}$ ), and oxazolone (retention time of $21 \mathrm{~min}$ ) were collected and freeze-dried.

\section{LC-MS/MS analysis of 8-oxodG, spiroiminodihydantoin, oxazolone, and guanidinohydantoin}

The dried samples containing 8-oxodG, oxazolone, spiroiminodihydantoin or guanidinohydantoin and their corresponding isotopomers were dissolved in appropriate solvents: 8-oxodG in $50 \mathrm{mM}$ ammonium acetate, spiroiminodihydantoin and oxazolone in 3:7 and 3:2 acetonitrile/water mixtures, respectively, and guanidinohydantoin in water. An aliquot of each sample was analyzed by HPLC-ESI-MS/MS using an Agilent 1100 series HPLC system interfaced with an API-Sciex 3000 triple quadrupole mass spectrometer equipped with either a TurbolonSpray ${ }^{\mathrm{TM}}$ source or, for the analysis of guanidinohydantoin, a nanoelectrospray ionization source. Chromatographic isolation of 8-oxodG was achieved using a $50 \times 2.1 \mathrm{~mm}$, $5 \mu \mathrm{m}$ C18 Zorbax Eclipse XDB-C18 column, using $50 \mathrm{mM}$ ammonium acetate (A) and acetonitrile (B) delivered from 0 to $15 \%$ B over $40 \mathrm{~min}$ at $0.2 \mathrm{~mL} / \mathrm{min}$. Oxazolone and spirominodihydantoin were separated on a $4.6 \times 75 \mathrm{~mm}, 5 \mu \mathrm{m}$ Zorbax XDB-C18 column, with a mobile phase of $0.1 \%$ acetic acid in water ( $\mathrm{pH} 4.5)(\mathrm{A})$ and acetonitrile (B) delivered isocratically ( $40 \% \mathrm{~A}$ and $60 \% \mathrm{~B}$ ) at $0.3 \mathrm{~mL} / \mathrm{min}$. Guanidinohydantoin was isolated on a $15 \mathrm{~cm}$ PicoFrit ${ }^{\mathrm{TM}}$ capillary column (360 $\mu \mathrm{M}$ OD x $75 \mu \mathrm{M}$ ID) (New Objective, Woburn, MA) packed with Alltech C18 $(5 \mu \mathrm{M})$. The mobile phase - $0.4 \%$ acetic acid in water (A) and $0.4 \%$ acetic acid in acetonitrile (B) - 97:3, respectively - was delivered at $90 \mathrm{~nL} / \mathrm{min}$. The mass spectrometer was operated in the positive ion mode, with all instrument paramenters optimized for maximum sensitivity. Samples were analyzed in the selected reaction-monitoring (SRM) mode, which monitors collision-induced dissociation of a precursor ion to an abundant characteristic product ion. The analyses monitored the transitions of $m / z 284 \rightarrow \mathrm{m} / \mathrm{z} 168, \mathrm{~m} / \mathrm{z} 285 \rightarrow \mathrm{m} / \mathrm{z}, 169$, and $m / z 287 \rightarrow m / z, 171$ (or $m / z 299 \rightarrow m / z$ 178) for 8-oxodG, $7-{ }^{15} \mathrm{~N}-8$-oxodG, $1,2,7-{ }^{15} \mathrm{~N}_{3}$-8oxo$\mathrm{dG}$ (or the uniformly ${ }^{13} \mathrm{C},{ }^{15} \mathrm{~N}$ labeled 8-oxodG), respectively (see supporting information Figure 10). Transitions of $\mathrm{m} / \mathrm{z} 247 \rightarrow \mathrm{m} / \mathrm{z} 131, \mathrm{~m} / \mathrm{z} 249 \rightarrow \mathrm{m} / \mathrm{z} 133$ and $\mathrm{m} / \mathrm{z} 259 \rightarrow \mathrm{m} / \mathrm{z} 138$ were monitored for oxazolone, 2,2-15 $\mathrm{N}_{2}$-oxazolone (from oxidation of $1,2,7-{ }^{15} \mathrm{~N}_{3}$-8-oxodG) and the uniformly ${ }^{13} \mathrm{C},{ }^{15} \mathrm{~N}$ labeled oxazolone (see supporting information Figure 11). Transitions of $m / z, 300 \rightarrow m / z 184, \rightarrow m / z 303 \rightarrow m / z$ 187, and $m / z 315 \rightarrow m / z 194$ were monitored for spiroiminodihydantoin, ${ }^{15} \mathrm{~N}_{3}$-spiroiminodihydantoin (from oxidation of $1,2,7-1{ }^{15} \mathrm{~N}_{3}$-8-oxodG), and the uniformly ${ }^{13} \mathrm{C},{ }^{15} \mathrm{~N}$ labeled spiroiminodihydantoin (see supporting information Figure 12 and 13). Transitions of $\mathrm{m} / \mathrm{z} 274 \rightarrow \mathrm{m} / \mathrm{z}$ 158, $\mathrm{m} / \mathrm{z} 288 \rightarrow \mathrm{m} /$ $z$ 167, and $m / z, 277 \rightarrow m / z, 161$ were monitored for guanidinohydantoin, the uniformly ${ }^{13} \mathrm{C},{ }^{15} \mathrm{~N}$ labeled guanidinohydantoin (from oxidation of the uniformly ${ }^{13} \mathrm{C},{ }^{15} \mathrm{~N}$ labeled 8-oxodG) and 3,7,8- ${ }^{15} \mathrm{~N}_{3}$-5-guanidinohydantoin (see supporting information Figure 14). Calibration curves for the labeled and unlabeled forms of each of the four DNA oxidation 
products were constructed by plotting the SRM signal ratios between the labeled and unlabeled forms against their corresponding concentration ratios. Quantitation of 8-oxodG, oxazolone, spiroiminodihydantoin, and guanidinohydantoin in each sample was achieved using the SRM signal ratio between analyte of interest and its isotope labeled internal standard and the response curve.

The limit of detection of 8-oxodG, oxazolone, spiroiminodihydantoin or guanidinohydantoin was measured by adding a known amount of the corresponding labeled nucleoside to DNA. Typically, 200 femtomol of the labeled nucleoside was added to $117 \mu \mathrm{g}$ of untreated DNA (the level of the labeled nucleoside is 5.6 nucleosides $/ 10^{7}$ nucleosides). DNA was digested to the nucleoside level. The labeled nucleoside was purified by HPLC and analyzed by LC-MS/MS as described above. For each labeled nucleoside, the signal-to-noise ratio e was $\sim 10$. The limit of detection was $\sim 1$ nucleoside $/ 10^{7}$ nucleosides with a signal to noise ratio of 2 . Assuming a response ratio of $\sim 1$ between signals of the unlabeled and the labeled nucleosides in the SRM mode, the limit of detection of each oxidation product (the unlabeled nucleoside) would also be $\sim 1$ nucleoside $/ 10^{7}$ nucleosides.

\section{dG from DNA digestion}

The amount of dG in the HPLC fraction containing $7-{ }^{15} \mathrm{~N}-\mathrm{dG}$ and dG from DNA digestion was measured by nano-LC-ESI-MS/MS on a capillary C18 column at a flow rate of $120 \mathrm{~nL} /$ $\min$. The mobile phase was an isocratic mixture of $0.4 \%$ acetic acid in water (A) and $0.4 \%$ acetic acid in acetonitrile (B) at 97\% A and 3\% B. SRM transitions of 268152 and 269153 were used to measure $\mathrm{dG}$ and $7-{ }^{15} \mathrm{~N}-\mathrm{dG}$, respectively. The amount of $\mathrm{dG}$ in each sample was calculated from the response curve obtained from the SRM signal ratios between $\mathrm{dG}$ and $7-{ }^{15} \mathrm{~N}-\mathrm{dG}$ and their corresponding concentration ratios.

\section{8-OxodG and spiroiminodihydantoin in DNA digested with different enzymes}

Untreated calf thymus DNA was digested with enzymes in various combinations:nuclease P1 and white potato acid phosphatase, nuclease P1, phosphodiesterase I and alkaline phosphatase, phosphodiesterase I (5'-exo digestion) and alkaline phosphatase, phosphodiesterase II (3'-exo digestion) and alkaline phosphatase (33). The uniformly ${ }^{13} \mathrm{C},{ }^{15} \mathrm{~N}$ labeled spiroiminodihydantoin and $1,2,7-{ }^{15} \mathrm{~N}-8$-oxodG were added to DNA before the digestion. Spiroiminodihydantoin and 8-oxodG were purified and quantitated as described above.

\section{Results}

We studied the formation in vitro and quantitation of four important DNA damage products 8-oxodG, oxazolone, spiroiminodihydantoin, and guanidinohydantoin - arising from treatment of calf thymus DNA with $\mathrm{ONOO}^{-}$via bolus addition. To ensure reliable quantitation, we synthesized ${ }^{13} \mathrm{C},{ }^{15} \mathrm{~N}$ labeled standards for each of the four analytes (26). Calf thymus DNA was reacted with $\mathrm{ONOO}^{-}$, desalted, and digested down to the nucleoside level using a cocktail of enzymes. The presence of a particular oxidation product in the $\mathrm{ONOO}^{-}$treated DNA was determined by HPLC purification followed by LC-MS/MS analysis in SRM mode. The optimized HPLC-ESI-MS/MS conditions allowed detection at femtomole levels (on-column) for all four oxidation products.

\section{Analysis of 8-oxodG}

The uniformly ${ }^{13} \mathrm{C},{ }^{15} \mathrm{~N}$ labeled 8 -oxodG was synthesized with a $10 \%$ yield. Its identity was confirmed by its characteristic UV spectrum $\left(\lambda_{\max }=248\right.$ and $\left.292 \mathrm{~nm}\right)$ and by ESI-MS, which gave a protonated molecule at $\mathrm{m} / z 299\left(\left[\mathrm{M}+\mathrm{H}^{+}\right]^{+}\right)$. Two fragment ions were observed, at $\mathrm{m} / \mathrm{z}$ $122\left(\left[\mathrm{M}+\mathrm{H}^{+}-178\right]\right)$ and $m / z .178\left([\mathrm{BH}+\mathrm{H}]^{+}\right)$, corresponding to the protonated ${ }^{13} \mathrm{C}_{5}$-deoxyribose and ${ }^{13} \mathrm{C}_{5},{ }^{15} \mathrm{~N}_{5}$-8-oxoguanine(see supporting information Figure 2). The amount of 8-oxodG 
formed in calf thymus DNA treated with $0,0.011,0.022,0.055,0.11,0.22,0.55,1.1,2.2$ and $4.4 \mu \mathrm{mol}$ of $\mathrm{ONOO}^{-}$(corresponding to $0,0.1,0.2,0.5,1,2,5,10,20$ and 40 equivalents of the guanine content in DNA) was determined by HPLC-MS/MS. To minimize formation of 8 oxodG from metal-catalyzed oxidation of dG during the DNA digestion and work-up, $0.1 \mathrm{mM}$ of desferrioxamine, a metal chelator, was added to the digestion mixture (34). To evaluate its effectiveness, $75 \mathrm{nmol}$ of ${ }^{7-}{ }^{15} \mathrm{~N}-\mathrm{dG}(\sim$ the same amount as $\mathrm{dG}$ obtained from complete digestion of $117 \mu \mathrm{g}$ of DNA) was added to DNA before the digestion. The labeled dG served two purposes, i.e., 1.) as an internal standard for LC-MS/MS analysis of dG, and 2.) to calculate the amount of 8-oxodG that formed adventitiously from $\mathrm{dG}$ during the overall experiment, assuming that $7-{ }^{15} \mathrm{~N}-\mathrm{dG}$ would be oxidized to the same extent as $\mathrm{dG}$ during DNA digestion and work-up. During the MS/MS analysis of 8-oxodG, SRM transitions of $m / z 284 \rightarrow m / z$ 168, $m / z 285 \rightarrow m / z 169, m / z, 287 \rightarrow m / z, 171($ or $m / z, 299 \rightarrow m / z, 178)$ were used to quantitate 8oxodG and $7-{ }^{15} \mathrm{~N}-8$-oxodG with $1,2,7-{ }^{15} \mathrm{~N}_{3}-8$ oxo-dG (or the uniformly ${ }^{13} \mathrm{C},{ }^{15} \mathrm{~N}$ labeled 8oxodG) as the internal standard (supporting information Figure 10). The presence of a significant amount of the $m / z 285 \rightarrow m / z 169$ transition demonstrated that $7-{ }^{15} \mathrm{~N}-\mathrm{dG}$ was oxidized to $7-{ }^{15} \mathrm{~N}$-8-oxodG during the digestion and work-up despite the presence of desferrioxamine in the digestion mixture, suggesting in turn that artifactual oxidation of dG to 8-oxodG also occurred. The amount of $\mathrm{dG}$ obtained from DNA digestion was quantitated using LC-MS/MS with $7-1{ }^{15} \mathrm{~N}-\mathrm{dG}$ as the internal standard. SRM transitions of $m / z 268 \rightarrow m / z 152$ and $m / z, 269 \rightarrow m / z, 153$ were used to measure $\mathrm{dG}$ and $7-{ }^{15} \mathrm{~N}-\mathrm{dG}$, respectively. With the molar ratio between $\mathrm{dG}$ and $7-{ }^{15} \mathrm{~N}-\mathrm{dG}$ and the amount of $7-{ }^{15} \mathrm{~N}-8$-oxodG known, the artifactual 8oxodG was calculated according to the equation: 8 -oxodG artifacts $=7-1{ }^{15} \mathrm{~N}-8$-oxodG $*$ molar ratio $\left(\mathrm{dG} / 7-{ }^{15} \mathrm{~N}-\mathrm{dG}\right)$; this amounted to approximately 58 -oxodG $/ 10^{6}$ nucleosides. There is some uncertainty with respect to this value due to the contribution of the ${ }^{13} \mathrm{C}$ isotope peak from the unlabeled 8-oxoG to the monoisotopic ${ }^{12} \mathrm{C}$ signal from the labeled standard. Since this effect would be at most about $6 \%$ for a $1: 1$ mixture of the two compounds $\left(1.1 \%{ }^{13} \mathrm{C}\right.$ for each of the 5 carbons in the fragment ion), we did not apply a correction. The amount of authentic 8 -oxodG in calf thymus DNA resulting from $\mathrm{ONOO}^{-}$treatment was calculated by subtracting the artifacts from the measured 8-oxodG values. The overall trend for the formation of 8-oxodG was dose-dependent except at 5 equivalents of $\mathrm{ONOO}^{-}$, at which the 8-oxodG level was lower than for either 2 equivalents or 10 equivalents of $\mathrm{ONOO}^{-}$(Figure 1).

\section{Analysis of oxazolone}

The uniformly ${ }^{13} \mathrm{C},{ }^{15} \mathrm{~N}$ labeled oxazolone and ${ }^{3} \mathrm{H}$-oxazolone were synthesized as described in materials and methods. Their identities were confirmed by their UV spectra $\left(\lambda_{\max }=232 \mathrm{~nm}\right)$ and by comparing their HPLC retention times to that of the unlabeled oxazolone. ESI-MS of the uniformly ${ }^{13} \mathrm{C},{ }^{15} \mathrm{~N}$ labeled oxazolone gave the $\left[\mathrm{M}+\mathrm{H}^{+}\right]^{+}$ion at $\mathrm{m} / z 259$ along with diagnostic fragment ions at $m / z 214\left(\left[\mathrm{M}-\mathrm{CO}_{2}+\mathrm{H}\right]^{+}\right), \mathrm{m} / z 138$ (protonated ${ }^{13} \mathrm{C}_{3},{ }^{15} \mathrm{~N}_{4}$-oxazolone base) and $m / z, 122$ (protonated ${ }^{13} \mathrm{C}_{5}$-deoxyribose). The molar extinction coefficient for the oxazolone nucleoside was measured at $0.009 \mathrm{M}^{-1} \mathrm{~cm}^{-1}$ (lambda; $\max =232 \mathrm{~nm}$ in water). Artifacts of oxazolone formed from oxidation of 8-oxodG during the DNA digestion and workup were evaluated by adding $1,2,7-{ }^{15} \mathrm{~N}_{3}-8$ oxodG to calf thymus DNA before the digestion and by monitoring the transitions of $m / z 247 \rightarrow m / z 131$ (oxazolone), $m / z, 249 \rightarrow m / z .133$ $\left(2,2-{ }^{15} \mathrm{~N}_{2}\right.$-oxazolone), and $m / z, 259 \rightarrow m / z 138$ (the uniformly ${ }^{13} \mathrm{C},{ }^{15} \mathrm{~N}$ labeled oxazolone) during the MS/MS analysis (supporting information Figure 11). Only the transition corresponding to the internal standard $(\mathrm{m} / z 259 \rightarrow \mathrm{m} / \mathrm{z}$ 138) was observed, i.e., the background levels of oxazolone in calf thymus DNA and the artifactual formation of oxazolone from 8oxodG during DNA digestion and work-up were both below the detection limit of 1 oxazolone/ $10^{7}$ bases. The amount of oxazolone formed in calf thymus DNA treated with $0,0.11,0.55$, $1.1,2.2$ and $4.4 \mu \mathrm{mol}$ of $\mathrm{ONOO}^{-}$(corresponding to $0,1,5,10,20$ and 40 equivalents of the guanine content in DNA) was determined using LC-MS/MS with the ${ }^{13} \mathrm{C},{ }^{15} \mathrm{~N}$ labeled oxazolone as the internal standard. That oxazolone was not detected in untreated calf thymus 
DNA also suggests that oxidation of dG to oxazolone during the DNA digestion and work-up is relatively insignificant. Figure 2 illustrates the dose-dependent formation of oxazolone from calf thymus DNA treated with different amounts of $\mathrm{ONOO}^{-}$.

\section{Analysis of spiroiminodihydantoin}

The ${ }^{13} \mathrm{C},{ }^{15} \mathrm{~N}$ labeled spiroiminodihydantoin and ${ }^{3} \mathrm{H}$-spiroiminodihydantoin were synthesized as described in materials and methods. Identities of the labeled compounds were confirmed by UV spectra and HPLC retention times. ESI-MS of the ${ }^{13} \mathrm{C},{ }^{15} \mathrm{~N}$ labeled spiroiminodihydantoin gave a protonated molecule at $m / z 315\left(\left[\mathrm{M}+\mathrm{H}^{+}\right]^{+}\right)$, along with characteristic fragment ions including $\mathrm{m} / z 194$ (protonated ${ }^{13} \mathrm{C}_{5},{ }^{15} \mathrm{~N}_{5}$-spiroiminodihydantoin base) and $\mathrm{m} / z .122$ (protonated ${ }^{13} \mathrm{C}_{5}$-deoxyribose). The molar extinction coefficient for the spiroiminodihydantoin nucleoside was determined to be $0.0105 \mathrm{M}^{-1} \mathrm{~cm}^{-1}$ at $\lambda_{\max }=230 \mathrm{~nm}$, which is over two-fold higher than the reported value of $4.3 \mathrm{mM}^{-1} \mathrm{~cm}^{-1}$ (31). The amount of spiroiminodihydantoin formed in calf thymus DNA treated with $0,0.011,0.022,0.055,0.11$ and $1.1 \mu \mathrm{mol}$ of $\mathrm{ONOO}^{-}$(corresponding to $0,0.1,0.2,0.5,1$ and 10 equivalents of the guanine content in DNA) was determined by LC-MS/MS with 128 pmol of the ${ }^{13} \mathrm{C},{ }^{15} \mathrm{~N}$ labeled spiroiminodihydantoin as the internal standard. Artifacts of spiroiminodihydantoin formed from 8-oxodG during DNA digestion and work-up were evaluated by adding $1,2,7-{ }^{15} \mathrm{~N}_{3}-8$-oxodG and the uniformly ${ }^{13} \mathrm{C},{ }^{15} \mathrm{~N}$ labeled spiroiminodihydantoin to DNA before the digestion and by subsequently monitoring SRM transitions of $m / z 300 \rightarrow m / z 184$ (spiroiminodihydantoin), $m /$ $z 303 \rightarrow m / z 187\left({ }^{15} \mathrm{~N}_{3}\right.$-spiroiminodihydantoin from oxidation of $1,2,7-{ }^{15} \mathrm{~N}_{3}-8$-oxodG), and $m / z 315 \rightarrow m / z 194$ (the uniformly ${ }^{13} \mathrm{C},{ }^{15} \mathrm{~N}$ labeled spiroiminodihydantoin) (supporting information Figure 12). There were significant SRM signals of both spiroiminodihydantoin and ${ }^{15} \mathrm{~N}_{3}$-spiroiminodihydantoin. The amount of ${ }^{15} \mathrm{~N}_{3}$-spiroiminodihydantoin formed during the digestion and work-up was $3.7 \pm 0.3 \mathrm{~mol} \%$ of $1,2,7-{ }^{15} \mathrm{~N}_{3}$-8-oxodG added to the digestion mixture. Assuming that 8-oxodG would be oxidized to the same extent as the isotopomer, the amount of spiroiminodihydantoin from artifactual oxidation of 8-oxodG was calculated as artifacts $=0.037 * 8$-oxodG. The authentic spiroiminodihydantoin was calculated by subtracting the artifacts from the measured spiroiminodihydantoin values. Figure 3 depicts spiroiminodihydantoin formed from DNA treated with different amounts of $\mathrm{ONOO}^{-}$. Although it was formed in a dose-dependent manner at low $\mathrm{ONOO}^{-}$doses $\left(\mathrm{ONOO}^{-}\right.$up to 0.2 equivalent of guanine content in DNA), its formation dropped significantly at higher $\mathrm{ONOO}^{-}$doses.

\section{Analysis of guanidinohydantoin}

Synthesis of $3,7,8-{ }^{15} \mathrm{~N}_{3}-5$-guanidinohydantoin, starting with $1,7, \mathrm{NH}_{2}{ }^{15} \mathrm{~N}_{3^{-}}-{ }^{\prime}-$ deoxyguanosine, is described in detail elsewhere (26). The amount of guanidinohydantoin formed in calf thymus DNA treated with $0,0.011,0.022,0.055,0.22$ and $2.2 \mu \mathrm{mol}$ of $\mathrm{ONOO}^{-}$(corresponding to $0,0.1,0.2,0.5,2$ and 20 equivalents of the guanine content in DNA) was determined by LC-MS/MS with 40.5 pmol of 3,7,8- ${ }^{15} \mathrm{~N}_{3}$-5-guanidinohydantoin as the internal standard. Artifactual formation of guanidinohydantoin was evaluated by adding the ${ }^{13} \mathrm{C},{ }^{15} \mathrm{~N}$ labeled 8-oxodG and 3,7,8- ${ }^{15} \mathrm{~N}_{3}$-5-guanidinohydantoin to DNA before the digestion and by subsequently monitoring SRM transitions of $\mathrm{m} / z$ 274 $\rightarrow \mathrm{m} / \mathrm{z} 158$ (guanidinohydantoin), $m / z 288 \rightarrow m / z 167$ (the uniformly ${ }^{13} \mathrm{C},{ }^{15} \mathrm{~N}$ labeled guanidinohydantoin from oxidation of the uniformly ${ }^{13} \mathrm{C},{ }^{15} \mathrm{~N}$ labeled 8-oxodG), and $\mathrm{m} / \mathrm{z} 277 \rightarrow \mathrm{m} / \mathrm{z} 161$ $\left(3,7,8-{ }^{15} \mathrm{~N}_{3}-5\right.$-guanidinohydantoin) (supporting information Figure 14). Significant amounts of guanidinohydantoin and its ${ }^{13} \mathrm{C},{ }^{15} \mathrm{~N}$ isotopomer were detected. The ${ }^{13} \mathrm{C},{ }^{15} \mathrm{~N}$ labeled guanidinohydantoin formed during DNA digestion and work-up was $0.6 \pm 0.06 \mathrm{~mol} \%$ of the uniformly ${ }^{13} \mathrm{C},{ }^{15} \mathrm{~N}$ labeled 8 -oxodG added to DNA before the digestion. Based on the assumption that 8-oxodG would be oxidized to the same extent as the labeled 8-oxodG in the digestion mixture, the amount of artifactual guanidinohydantoin was calculated according to the equation: artifacts $=0.006 * 8$-oxodG, and the authentic guanidinohydantoin was calculated by subtracting the artifacts from the measured guanidinohydantoin values. Figure 4 depicts 
guanidinohydantoin formed from DNA treated with different amounts $\mathrm{ONOO}^{-}$. As with spiroiminodihydantoin, formation of guanidinohydantoin was dose-dependent at low $\mathrm{ONOO}^{-}$doses $\left(\mathrm{ONOO}^{-}\right.$up to 0.2 equivalent of total guanine in DNA) and its formation dropped significantly to the basal level at high $\mathrm{ONOO}^{-}$doses.

\section{Yields of 8-oxodG and spiroiminodihydantoin from different digestion methods}

Cadet, et al., reported that enzymatic hydrolysis of phosphodiester bonds between 4,8dihydro-4-hydroxy-8-oxo-dG (later to be corrected as spiroiminodihydantoin (13) and normal 2 '-deoxyribonucleosides in oligonucleotides was inhibited with both endonucleases and exonucleases (33). In order to evaluate the effects of various enzymes on the formation of 8oxodG and spiroiminodihydantoin, untreated calf thymus DNA was digested with 1.) nuclease P1 and white potato acid phosphatase; 2.) nuclease P1, phosphodiesterase I and alkaline phosphatase; 3.) phosphodiesterase II (3'-exo digestion) and alkaline phosphatase; and 4.) phosphodiesterase I (5'-exo digestion) and alkaline phosphatase. The uniformly ${ }^{13} \mathrm{C},{ }^{15} \mathrm{~N}$ labeled spiroiminodihydantoin and $1,2,7-1{ }^{15} \mathrm{~N}-8$-oxodG were added to the DNA before digestion. The results are summarized in Table 1. Surprisingly, the yields of spiroiminodihydantoin were similar among the various enzyme combinations. The yield of 8oxodG from acidic digestion, however, was significantly lower than that from other enzymatic digestion methods.

\section{Discussion}

The reaction of $\mathrm{ONOO}^{-}$with $\mathrm{dG}$ yields a number of primary and secondary oxidation products including 8-oxodG, oxazolone, spiroiminodihydantoin and guanidinohydantoin. Indications that these four products may also be formed from oxidation of guanine base in DNA or oligonucleotides have emerged during the past decade. 8-OxodG is a ubiquitous DNA oxidation product both with isolated DNA and cellular DNA (35). The level of 8-oxodG has been reported to increase dose-dependently in calf thymus DNA treated with singlet $\mathrm{O}_{2}$ (36). Oxazolone and its precursor imidazolone have been observed as oxidation products of guanine or 8-oxoguanine in oligonucleotides and calf thymus DNA treated with Mn-TMPyP/KHSO 5 (37), $\mathrm{ONOO}^{-}(11,18)$, photochemical oxidants $(38-41)$, and $\gamma$-radiation (11).

Spiroiminodihydantoin has been observed as the final oxidation product of guanine base (likely via 8-oxoguanine) in oligonucleotides by carbonate radical anions (42) and by chromium species (43). Guanidinohydantoin has been detected in DNA treated with peroxo-Cr(V) (44) or in oligonucleotides containing 8-oxoguanine (45). Cadet and co-workers reported that the levels of oxazolone and 8-oxodG increased and decreased, respectively, in calf thymus DNA treated with $\mathrm{ONOO}^{-}(11)$. However, neither spiroiminodihydantoin nor guanidinohydantoin in calf thymus DNA treated with $\mathrm{ONOO}^{-}$has been reported. In this paper we describe the identification and quantitation, by LC-MS/MS, of 8-oxodG, oxazolone, spiroiminodihydantoin and guanidinohydantoin in calf thymus DNA following treatment with $\mathrm{ONOO}^{-}$. Detection of these oxidation products in vitro is a necessary first step toward profiling various $\mathrm{ONOO}^{-}$ related lesions that may be formed in vivo. Oxazolone, guanidinohydantoin and spiroiminodihydantoin have been shown in various studies to be strong blocking and/or highly mutagenic lesions $(24,25)$. Future research may reveal that the increased cancer risks associated with excess $\mathrm{ONOO}^{-}$production can be directly linked to the formation of specific lesions in DNA.

LC-MS/MS was chosen to detect and quantitate these DNA oxidation products because it combines the power of on-line purification by liquid chromatography with the specificity and sensitivity of tandem mass spectrometry. The SRM mode was used because all of the four products share the characteristic fragmentation pattern of splitting of the $\mathrm{N}$-glycosidic bond from the pseudo-molecular ions $\left(\left[\mathrm{M}+\mathrm{H}^{+}\right]^{+}\right)$of the analytes. The $\left[\mathrm{M}+\mathrm{H}^{+}\right]^{+}$ions were selected 
in Q1, fragmented in Q2, and the protonated bases $\left(\left[\mathrm{BH}+\mathrm{H}^{+}\right]^{+}\right)$of the analytes were selected in Q3. This specific and sensitive assay allowed a detection limit of 1 lesion $/ 10^{7}$ bases for all four DNA oxidation products. All the stable-isotope labeled standards of the four DNA oxidation products were tested to assure that no false positives were introduced by the internal standards.

Artifactual formation of 8-oxodG during DNA digestion and work-up is common (46). It was reported that the presence of desferrioxamine during digestion would greatly reduce fentontype oxidation of $\mathrm{dG}$ (47). Our results confirm that this reduction is not complete. Under our DNA digestion and work-up conditions, artifactual 8-oxodG was about 5/10 6 nucleosides. Artifacts of oxazolone, spiroiminodihydanotin and guanidinohydantoin could also emerge during the DNA digestion and work-up, from oxidation of dG or 8-oxodG or both. This possibility was assessed by LC/MS using the various SRM transitions described earlier. No $2,2-{ }^{15} \mathrm{~N}_{2}$-Oxazolone was detected, suggesting little or no artifactual formation of oxazolone. ${ }^{15} \mathrm{~N}_{3}$-spiroiminodihydantoin and the uniformly ${ }^{13} \mathrm{C},{ }^{15} \mathrm{~N}$ labeled guanidinohydantoin, however, were detected at $3.7 \mathrm{~mol} \%$ and $0.6 \mathrm{~mol} \%$ of the corresponding labeled 8-oxodG, respectively. In fact, the formation of these two compounds from oxidation of 8-oxodG during the DNA digestion and work-up, with preferential formation of spiroiminodihydantoin at $\mathrm{pH} \sim 7$, was not surprising $(31,48,49)$ and it is clear that care must be taken during their analysis to avoid false positives.

The dose-response studies of the formation of 8-oxodG, oxazolone, spiroiminodihydantoin and guanidinohydantoin in DNA treated with $\mathrm{ONOO}^{-}$provided better understanding of the mechanism of formation of these lesions in DNA. The basal level of 8-oxodG in calf thymus DNA determined by us was approximately 128 -oxoguanine $/ 10^{6}$ bases (or about 508 oxoguanine $/ 10^{6}$ guanine bases), which is similar to literature values (11 8-oxoguanine $/ 10^{6}$ bases (36) or 61.6 8-oxoguanine $/ 10^{6}$ guanine bases (50). The amount of 8-oxodG increased up to 2 equivalents of $\mathrm{ONOO}^{-}$treatment and then began to decrease until 10 equivalents of $\mathrm{ONOO}^{-}$treatment, after which it increased again in a dose-dependent fashion. This behavior could be due to differences, at each $\mathrm{ONOO}^{-}$dose, in the competition between the accumulation of 8-oxoguanine from oxidation of guanine by $\mathrm{ONOO}^{-}$and further reaction of 8-oxoguanine with $\mathrm{ONOO}^{-}$to its secondary oxidation products.

It was somewhat surprising that the background level of oxazolone in calf thymus DNA was below the detection limit of 1 lesion $/ 10^{7}$ bases. Since it is a stable end-product from reaction of $\mathrm{dG}$ and $\mathrm{ONOO}^{-}$, its formation in a dose-dependent manner in DNA is expected, e.g., Douki and Cadet have also shown that oxazolone is produced from the reaction of calf thymus DNA with peroxynitrite (11).

Spiroiminodihydantoin and guanidinohydantoin, both considered as secondary oxidation products from the oxidation of 8-oxodG $(13,19,31,49)$, were formed in DNA in a dosedependent manner at low $\mathrm{ONOO}^{-}$doses with their levels increasing up to 0.2 equivalents of $\mathrm{ONOO}^{-}$treatment. Their formation, however, dropped significantly at high $\mathrm{ONOO}^{-}$doses (> 10 equivalents of $\mathrm{ONOO}^{-}$treatment). This could be explained as follows (Scheme 2): 8-oxodG undergoes two one-electron oxidations to a quinonoid intermediate (I). At low $\mathrm{ONOO}^{-}$doses, water (the predominant nucleophile) reacts with I to form II, which then undergoes decomposition to spiroiminodihydantoin or guanidinohydantoin. At higher $\mathrm{ONOO}^{-}$doses, however, $\mathrm{ONOO}^{-}$may also act as a nucleophile and react with I to afford III, which could then undergo decomposition to oxazolone, oxaluric acid or cyanuric acid (19). The background levels of spiroiminodihydantoin and guanidinohydantoin in calf thymus DNA were $12 / 10^{6}$ bases and $4 / 10^{6}$ bases, respectively, perhaps due to oxidation of pre-existing 8 -oxoguanine in DNA. 


\section{Conclusion}

In conclusion, we have quantitated 8-oxodeoxyguanosine, oxazolone, guanidinohydantoin and spiroiminodihydantoin from peroxynitrite-treated calf thymus DNA. The formation of these compounds demonstrates that $\mathrm{ONOO}^{-}$inflicts complex oxidative damage to guanine bases in DNA in vitro and suggests that elevated concentrations of $\mathrm{ONOO}^{-}$may induce oxidative damage to DNA under inflammatory conditions in vivo. Efforts to detect these lesions in DNA from tissues of mouse models of inflammation are underway.

\section{Supplementary Material}

Refer to Web version on PubMed Central for supplementary material.

\section{Acknowledgements}

Thanks to NIH (Grant No. CA26371 the MIT Center for Environmental Health Sciences (Grant No. ES002109) for financial support. We thank Dr. Julie Marr (Agilent) for her insight and technical assistance with the LC-MSD-TOF, and Agilent for graciously providing full access to the instrument.

\section{Abbreviations}

$\mathrm{ONOO}^{-}$

peroxynitrite

dG

2'-deoxyguanosine

8-oxodG

8-oxo-7, 8 dihydro-2'-deoxyguanosine

oxazolone

2,2-diamino-4[(2-deoxy- $\beta$-D-erythro-pentafuranosyl)amino]-5(2H)-oxazolone

imidazolone

2-amino-5-[2-deoxy- $\beta$-D-erythro-pentafuranosyl)amino]-4H-imidazol-4-one

guanidinohydantoin

$\mathrm{N}^{1}$-( $\beta$-D-erythro-pentofuranosyl)-5-guanidinohydantoin

dGTP

2'-deoxyguanosine triphosphate

SRM

selected reaction monitoring

\section{References}

1. Beckman JS. Oxidative Damage and Tyrosine Nitration by Peroxynitrite. Chem Res Toxicol 1996;9:836-844. [PubMed: 8828918]

2. Huie RE, Padmaja S. The reaction of NO with superoxide. Free Rad Res Comm 1993;18:195-199.

3. Szabo C, Zingarelli B, O'Connor M, Salzman AL. DNA strand breakage, activation of poly (ADPribose) synthetase, and cellular energy depletion are involved in the cytotoxicity of macrophages and smooth muscle cells exposed to peroxynitrite. Proc Natl Acad Sci U S A 1996;93:1753-1758. [PubMed: 8700830] 
4. Kaur H, Halliwell B. Evidence for nitric oxide-mediated oxidative damage in chronic inflammation. Nitrotyrosine in serum synovial fluid from rheumatoid patients. FEBS Lett 1994;350:9-12. [PubMed: 8062931]

5. Roediger WEW, Lawson MJ, Radcliffe BC. Nitrite from inflammatory cells-a cancer risk factor in ulcerative colitis? Dis Colon Rectum 1990;33:1034-1036. [PubMed: 2242698]

6. Salgo MG, Stone K, Squadrito GL, Battista JR, Pryor WA. Peroxynitrite causes DNA nicks in plasmid pBR322. Biochem Biophys Res Comm 1995;210:1025-1030. [PubMed: 7763229]

7. Szabo C, Ohshima H. DNA damage induced by peroxynitrite: subsequent biological effects. Nitric Oxide: Biol Chem 1997;1:373-385.

8. Kennedy LJ, Moore K Jr, Caulfield JL, Tannenbaum SR, Dedon PC. Quantitation of 8-oxoguanine and strand breaks produced by four oxidizing agents. Chem Res Toxicol 1997;10:386-392. [PubMed: 9114974]

9. Burney S, Niles JC, Dedon PC, Tannenbaum SR. DNA damage in deoxynucleosides and oligonucleotides treated with peroxynitrite. Chem Res Toxicol 1999;12:513-520. [PubMed: 10368314]

10. Burney S, Caulfield JL, Wishnok JS, Tannenbaum SR. The chemistry of DNA damage from nitric oxide and peroxynitrite. Mutat Res 1999;424:37-49. [PubMed: 10064848]

11. Douki T, Cadet J. Peroxynitrite mediated oxidation of purine bases of nucleosides and isolated DNA. Free Radic Res 1996;24:369-380. [PubMed: 8733941]

12. Niles JC, Burney S, Singh S, Wishnok JS, Tannenbaum SR. Peroxynitrite reaction products of 3',5'di-O-acetyl-8-oxo-7,8-dihydro-2'-deoxyguanosine. Proc Natl Acad Sci U S A 1999;96:11729_ 11734. [PubMed: 10518518]

13. Niles JC, Wishnok JS, Tannenbaum SR. Spiroiminodihydantoin is the major product of the 8-oxo-7,8dihydroguanosine reaction with peroxynitrite in the presence of thiols and guanosine photooxidation by methylene blue. Org Lett 2001;3:963-966. [PubMed: 11277770]

14. Yermilov V, Yoshie Y, Rubio J, Ohshima H. Effects of carbon dioxide/bicarbonate on induction of single-strand breaks and formation of 8-nitroguanine, 8-oxoguanine, and base propenal mediated by peroxynitrite. FEBS Lett 1996;399:67-70. [PubMed: 8980121]

15. Cadet J, Berger M, Buchko GW, Joshi PC, Raoul S, Ravanat JL. 2,2-Diamino-4-[(3,5-di-O-acetyl-2deoxy-beta-D-erythro- pentofuranosyl)amino]-5-(2H)-oxazolone: a novel and predominant radical oxidation product of 3',5'-Di-O-acetyl-2'-deoxyguanosine. J Am Chem Soc 1994;116:7403-7404.

16. Raoul S, Berger M, Buchko GW, Joshi PC, Morin B, Weinfeld M, Cadet J. Novel oxidation products of deoxyguanosine:oxazolone and imidazolone nucleosides. J Chem, Soc Perkin Trans 2 1996;2:371381.

17. Uppu RM, Cueto R, Squadrito GL, Salgo MG, Pryor WA. Competitive reactions of peroxynitrite with 2'-deoxyguanosine and 7,8-dihydro-8-oxo-2'-deoxyguanosine (8-oxodG): Relevance to the formation of 8-oxodG in DNA exposed to peroxynitrite. Free Rad Biol Med 1996;21:407-411. [PubMed: 8855454]

18. Tretyakova NY, Niles JC, Burney S, Wishnok JS, Tannenbaum SR. Peroxynitrite-induced reactions of synthetic oligonucleotides containing 8-oxoguanine. Chem Res Toxicol 1999;12:459-466. [PubMed: 10328757]

19. Niles JC, Wishnok JS, Tannenbaum SR. Spiroiminodihydantoin and guanidinohydantoin are the dominant reaction products of 8-oxoguanosine oxidation at low fluxes of peroxynitrite: mechanistic studies with 180. Chem Res Toxicol 2004;17:1510-1519. [PubMed: 15540949]

20. Wood ML, Dizdaroglu M, Gajewski E, Essigmann JM. Mechanistic studies of ionization radiation and oxidative mutagenesis: genetic effects of a single 8-hydroxyguanine (7-hydro-8-oxoguanine) residue inserted at a unique site in a viral genome. Biochemistry 1990;29:7024-7032. [PubMed: 2223758]

21. Moriya M, Ou C, Bodepudi V, Johnson F, Takeshita M, Grollman AP. Site-specific mutagenesis using a gapped duplex vector: a study of translesion synthesis past 8-oxodeoxyguanosine in E. coli. Mutat Res 1991;254:281-288. [PubMed: 2052015]

22. Klein JC, Bleeker MJ, Lutgerink JT, Van BJ, Brugghe HF, Van DE, Van der Marcel GA, Van BJ, Westra JG, Berns AJ. Use of shuttle vectors to study the molecular processing of defined carcinogen- 
induced DNA damage: mutagenicity of single O4-ethylthymine adducts in HeLa cells. Nucleic Acids Res 1990;18:4131-4137. [PubMed: 2377457]

23. Duarte V, Gasparutto D, Jaquinod M, Cadet J. In vitro DNA synthesis opposite oxazolone and repair of this DNA damage using modified oligonucleotides. Nucleic Acids Res 2000;28:1555-1563. [PubMed: 10710422]

24. Henderson PT, Delaney JC, Gu F, Tannenbaum SR, Essigmann JM. Oxidation of 7,8-dihydro-8oxoguanine affords lesions that are potent sources of replication errors in vivo. Biochemistry 2002;41:914-921. [PubMed: 11790114]

25. Henderson PT, Delaney JC, Muller JG, Neeley WL, Tannenbaum SR, Burrows CJ, Essigmann JM. The hydantoin lesions formed from oxidation of 7,8-dihydro-8-oxoguanine are potent sources of replication errors in vivo. Biochemistry 2003;42:9257-9262. [PubMed: 12899611]

26. Yu H, Wishnok JS, Tannenbaum SR. Synthesis of 3,7,8-15N3-(beta-D-erythropentafuranosyl)-5guanidinohydantoin. J Label Cmpds Radiopharm 2003;46:1269-1277.

27. Pryor WA, Cueto R, Jin X, Koppenol WH, Ngu-Schwemlein M, Squadrito GL, Uppu PL, Uppu RM. A practical method for preparing peroxynitrite solutions of low ionic strength and free of hydrogen peroxide. Free Rad Biol Med 1995;18:75-83. [PubMed: 7896174]

28. Kasai H, Nishimura S. Hydroxylation of deoxyguanosine at the C-8 position by ascorbic acid and other reducing agents. Nucleic Acids Res 1984;12:2137-2145. [PubMed: 6701097]

29. Gasparutto D, Ravanat JL, Gérot O, Cadet J. Characterization and chemical stability of photooxidized oligonucleotides that contain 2,2-diamino-4-[(2-deoxy-D-erythro-pentofuranosyl)amino]-5(2H)oxazolone. J Am Chem Soc 1998;120:10283-10286.

30. Ravanat J, Cadet J. Reaction of singlet oxygen with 2'-deoxyguanosine and DNA isolation and characterization of the main oxidation products. Chem Res Toxicol 1995;8:379-388. [PubMed: 7578924]

31. Luo W, Muller JG, Rachlin EM, Burrows CJ. Characterization of spiroiminodihydantoin as a product of one-electron oxidation of 8-oxo-7,8-dihydroguanosine. Org Lett 2000;2:613-616. [PubMed: 10814391]

32. Hughes MN, Nicklin HG. The chemistry of pernitrites. Part I Kinetics of decomposition of pernitrous acid. J Chem Soc 1968:450-452.

33. Romieu A, Gasparutto D, Molko D, Ravanat JL, Cadet J. Synthesis of oligonucleotides containing the $(4 \mathrm{R})$ and $(4 \mathrm{~S})$ diastereoisomers of 4,8-dihydro-4-hydroxy-8-oxo-2'-deoxyguanosine. Eur J Org Chem 1999;1:49-56.

34. Ravanat JL, Douki T, Duez P, Gremaud E, Herbert K, Hofer T, Lasserre L, Saint-Pierre C, Favier A, Cadet J. Cellular background level of 8-oxo-7,8-dihydro-2'-deoxyguanosine: an isotope based method to evaluate artefactual oxidation of DNA during its extraction and subsequent work-up. Carcinogenesis 2002;23:1911-1918. [PubMed: 12419840]

35. Helbock HJ, Beckman KB, Ames BN. 8-Hydroxy-deoxyguanosine and 8-hydroxyguanine as biomarkers of oxidative DNA damage. Methods Enzymol 1999;300:156-166. [PubMed: 9919519]

36. Ravanat JL, Saint-Pierre C, Di Mascio P, Martinez G, Medeiros MHG, Cadet J. Damage to isolated DNA mediated by singlet oxygen. Helv Chim Acta 2001;84:3702-3709.

37. Vialas C, Claparos C, Pratviel G, Meunier B. Guanine oxidation in double-stranded DNA by MnTMPyP/KHSO5: 5,8-dihydroxy-7,8-dihydroguanine residue as a key precursor of imidazolone and parabanic acid derivatives. J Am Chem Soc 2000;122:2157-2167.

38. Adam W, Grimm GN, Saha-Moeller CR, Dall'Acqua F, Miolo G, Vedaldi D. DNA damage by tertbutoxyl radicals generated in the photolysis of a water-soluble, DNA-binding peroxyester acting as a radical source. Chem Res Toxicol 1998;11:1089-1097. [PubMed: 9760284]

39. Adam W, Arnold MA, Grimm GN, Saha-Moeller CR, Dall'Acqua F, Miolo G, Vedaldi D. 4-tertButylperoxymethyl-9-methoxypsoralen as intercalating photochemical alkoxyl-radical source for oxidative DNA damage. Photochem Photobiol 1998;68(4):511-518. [PubMed: 9796433]

40. Adam W, Saha-Moeller CR, Schoenberger A. Photooxidation of 8-oxo-7,8-dihydro-2'deoxyguanosine by thermally generated triplet-excited ketones from 3-(hydroxymethyl)-3,4,4trimethyl-1,2-dioxetane and comparison with Type I and Type II photosensitizers. J Am Chem Soc 1996;118:9233-9238. 
41. Adam W, Andler S, Saha-Moeller CR, Schoenberger A. Inhibitory effect of ethyl oleate hydroperoxide and alcohol in photosensitized oxidative DNA damage. J Photochem Photobiol B: Biology 1996;34:51-58.

42. Joffe A, Geacintov NE, Shafirovich V. DNA lesions derived from the site selective oxidation of guanine by carbonate radical anions. Chem Res Toxicol 2003;16:1528-1538. [PubMed: 14680366]

43. Sugden KD, Campo CK, Martin BD. Direct oxidation of guanine and 7,8-dihydro-8-oxoguanine in DNA by a high-valent chromium complex: a possible mechanism for chromate genotoxicity. Chem Res Toxicol 2001;14:1315-1322. [PubMed: 11559048]

44. Joudah L, Moghaddas S, Bose RN. DNA oxidation by peroxo-chromium(V) species: oxidation of guanosine to guanidinohydantoin. Chem Comm 2002:1742-1743. [PubMed: 12196977]

45. Duarte V, Muller JG, Burrows CJ. Insertion of dGMP and dAMP during in vitro DNA synthesis opposite an oxidized form of 7,8-dihydro-8-oxoguanine. Nucleic Acids Res 1999;27:496-502. [PubMed: 9862971]

46. Halliwell B. Why and how should we measure oxidative DNA damage in nutritional studies? How far have we come? Am J Clin Nutr 2000;72:1082-1087. [PubMed: 11063432]

47. Helbock HJ, Beckman KB, Shigenaga MK, Walter PB, Woodall AA, Yeo HC, Ames BN. DNA oxidation matters: The HPLC-electrochemical detection assay of 8-oxo-deoxyguanosine and 8-oxoguanine. Proc Natl Acad Sci U S A 1998;95:288-293. [PubMed: 9419368]

48. Luo W, Muller JG, Burrows CJ. The $\mathrm{pH}$-dependent role of superoxide in riboflavin-catalyzed photooxidation of 8-oxo-7,8-dihydroguanosine. Org Lett 2001;3:2801-2804. [PubMed: 11529760]

49. Luo W, Muller JG, Rachlin EM, Burrows CJ. Characterization of hydantoin products from oneelectron oxidation of 8-oxo-7,8-dihydroguanosine in a nucleoside model. Chem Res Toxicol 2001;14:927-938. [PubMed: 11453741]

50. Collins A, Gedik C, Wood S, White A, Dubois J, Duez P, Rees JF, Legall R, Degand L, Loft S, Jensen A, Poulsen H, Weimann A, Jensen B, Cadet J, Douki T, Ravanat JL, Faure H, Tripier M, Morel I, Sergent O, Cillard P, Morin B, pe B, Phoa N, Hartwig A, Pelzer A, Dolara P, Casalini C, Guglielmi F, Luceri C, Kasai H, Kido R, Olinski R, Bialkowski K, Durackova Z, Hlincikova L, Korytar P, Dusinska M, Mislanova C, Vina J, Lloret A, Moller L, Hofer T, Gremaud E, Fay L, Stadler R, Eakins J, Pognan F, O'Brien J, Elliott R, Astley S, Bailley A, Herbert K, Chauhan D, Kelly F, Dunster C, Lunec J, Podmore I, Patel P, Johnson S, Evans M, White A, Tyrrell R, Gordon M, Wild C, Hardie L, Smith E. Inter-laboratory validation of procedure for measuring 8-oxo-7,8-dihydroguanine/8oxo-7,8-dihydro-2'-deoxyguanosine in DNA. Free Rad Res 2002;36:239-245. 


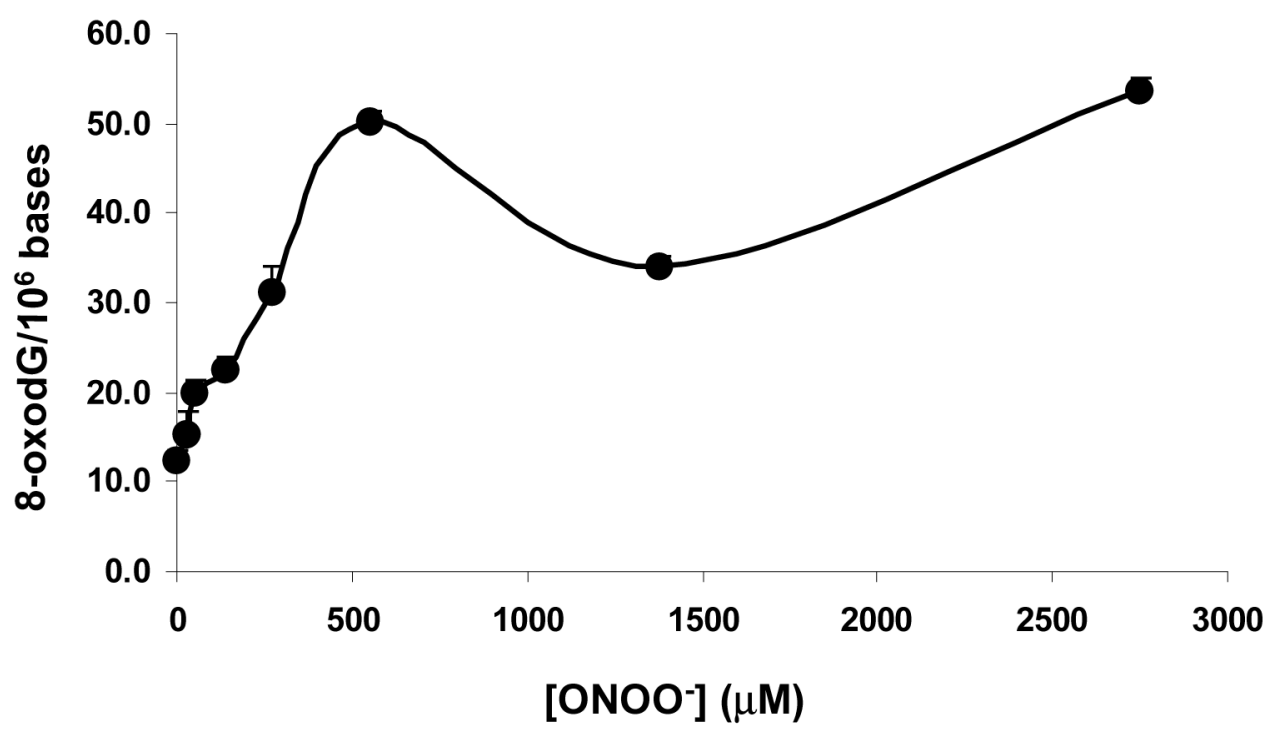

Figure 1.

The amount of 8-oxodG formed in calf thymus DNA treated with $0,0.011,0.022,0.055,0.11$, $0.22,0.55,1.1,2.2$ and $4.4 \mu \mathrm{mol}$ of $\mathrm{ONOO}^{-}$was determined by HPLC-MS/MS. To minimize formation of 8-oxodG from metal-catalyzed oxidation of $\mathrm{dG}$ during the DNA digestion and work-up, $0.1 \mathrm{mM}$ of desferrioxamine, a metal chelator, was added to the digestion mixture (34). Despite this precaution, artifactual 8-oxodG was observed, and the levels were estimated as described earlier. The amount of authentic 8-oxodG in calf thymus DNA resulting from $\mathrm{ONOO}^{-}$treatment was calculated by subtracting the artifacts from the measured 8-oxodG values. The data points represent duplicate analyses. 


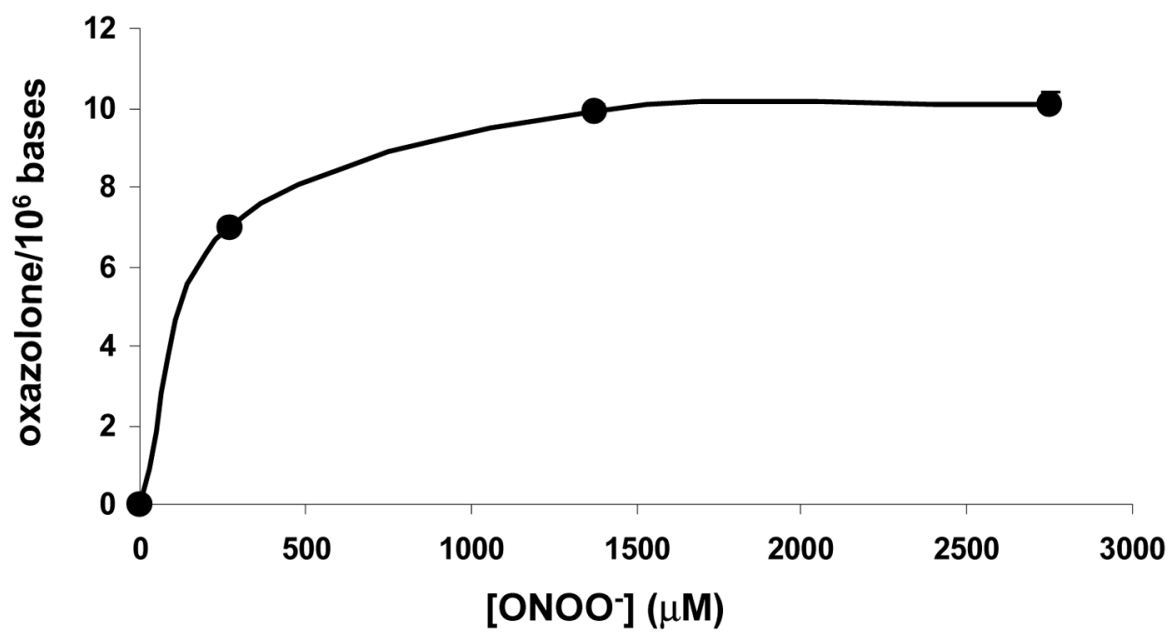

Figure 2.

Formation of oxazolone in calf thymus DNA treated with $0,275,1375$, and $2750 \mu \mathrm{M}$ $\mathrm{ONOO}^{-}$. Analysis was by LC-MS/MS with the ${ }^{13} \mathrm{C},{ }^{15} \mathrm{~N}$ labeled oxazolone as the internal standard. The data points represent duplicate analyses; the error bars fall within the data markers. Oxazolone was not detected in untreated calf thymus DNA, suggesting that oxidation of $\mathrm{dG}$ to oxazolone during the DNA digestion and work-up is relatively insignificant. The data points represent duplicate analyses. 


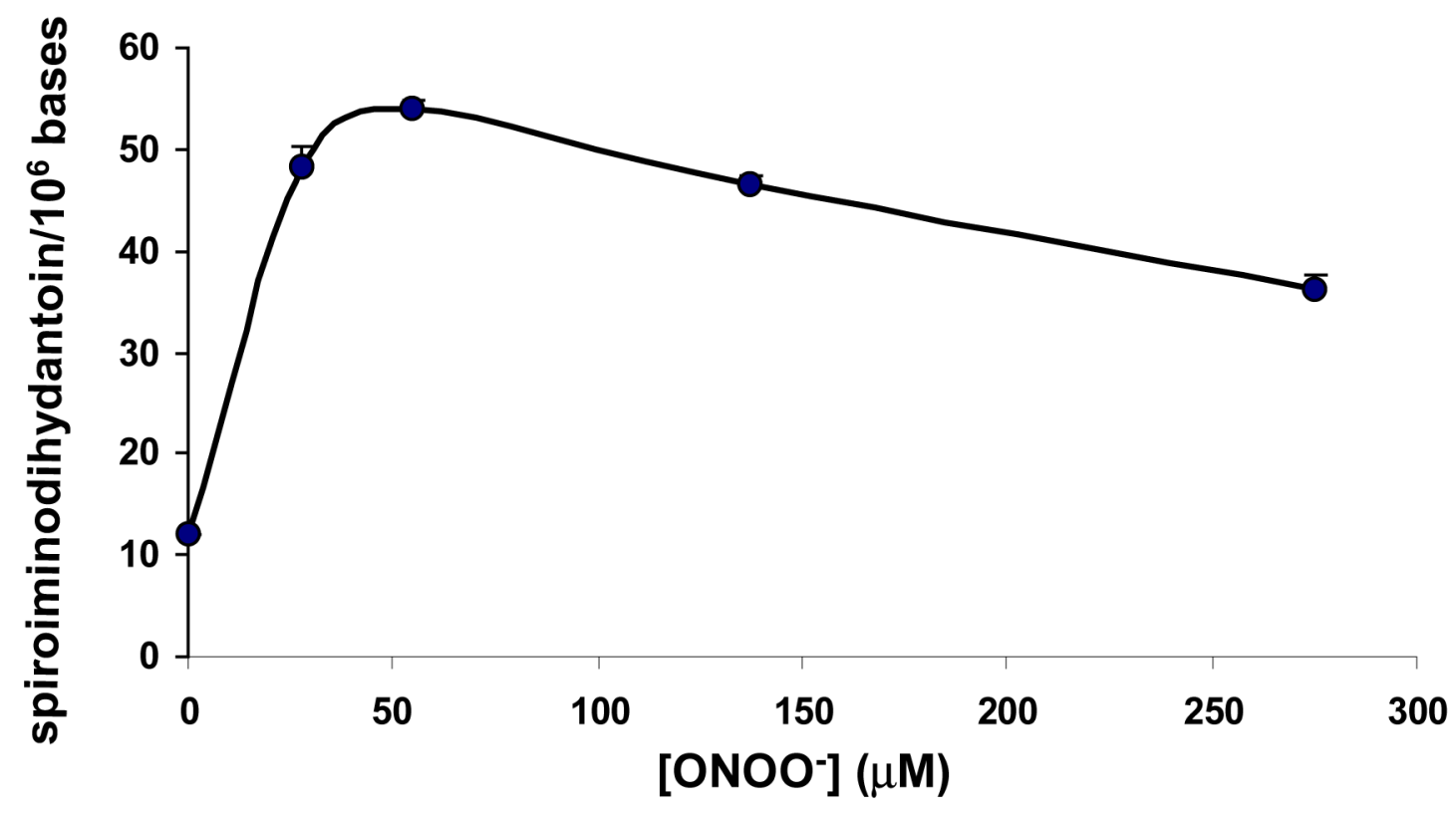

Figure 3.

Formation of spiroiminodihydantoin formed in calf thymus DNA treated with varying amounts of peroxynitrite. Quantitation was by LC-MS/MS with ${ }^{13} \mathrm{C},{ }^{15} \mathrm{~N}$ labeled spiroiminodihydantoin as the internal standard. Artifactual formation was evaluated by adding $1,2,7-{ }^{15} \mathrm{~N}_{3}-8$-oxodG and uniformly ${ }^{13} \mathrm{C},{ }^{15} \mathrm{~N}$ labeled spiroiminodihydantoin to DNA before the digestion and by subsequently monitoring SRM transitions of $m / z \quad 300 \rightarrow m / z 184$ (spiroiminodihydantoin), $m /$ $z 303 \rightarrow m / z 187\left({ }^{15} \mathrm{~N}_{3}\right.$-spiroiminodihydantoin from oxidation of $1,2,7-{ }^{15} \mathrm{~N}_{3}$-8-oxodG), and $\mathrm{m} / \mathrm{z} 315 \rightarrow \mathrm{m} / \mathrm{z} 194$ (the uniformly ${ }^{13} \mathrm{C},{ }^{15} \mathrm{~N}$ labeled spiroiminodihydantoin). The data points represent duplicate analyses. 


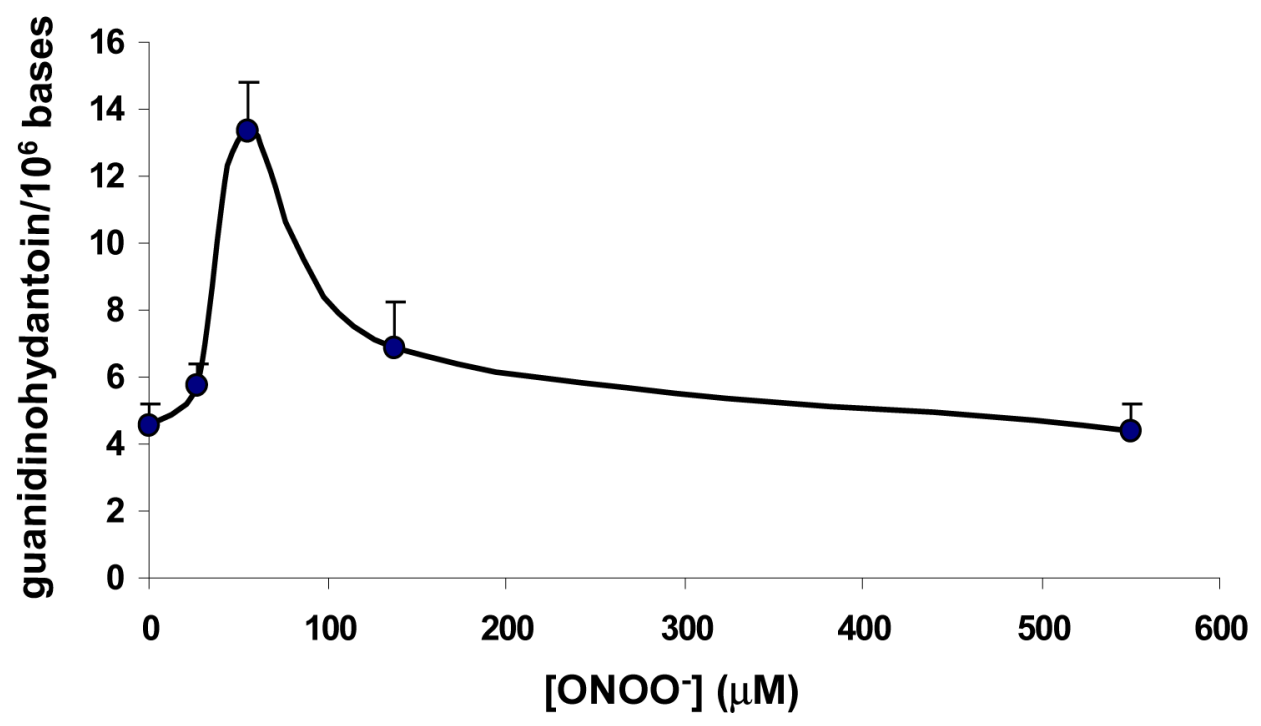

Figure 4.

The levels of guanidinohydantoin formed in calf thymus DNA treated with varying guanidinohydantoin as the internal standard. Artifactual formation of guanidinohydantoin was amounts of $\mathrm{ONOO}^{-}$were determined by LC-MS/MS with 40.5 pmol of 3,7,8- ${ }^{15} \mathrm{~N}_{3}$-5-evaluated by adding the ${ }^{13} \mathrm{C},{ }^{15} \mathrm{~N}$ labeled 8 -oxodG and 3,7,8- ${ }^{15} \mathrm{~N}_{3}-5$-guanidinohydantoin to DNA before the digestion and by subsequently monitoring SRM transitions of $m / z 274 \mathrm{~m} / z .158$ (guanidinohydantoin), $\mathrm{m} / \mathrm{z} 288 \mathrm{~m} / \mathrm{z}, 167$ (the uniformly ${ }^{13} \mathrm{C},{ }^{15} \mathrm{~N}$ labeled guanidinohydantoin from oxidation of the uniformly ${ }^{13} \mathrm{C},{ }^{15} \mathrm{~N}$ labeled 8-oxodG), and $\mathrm{m} / \mathrm{z}, 277 \rightarrow \mathrm{m} / \mathrm{z}, 161$ $\left(3,7,8-{ }^{15} \mathrm{~N}_{3}-5\right.$-guanidinohydantoin). The data points represent duplicate analyses. 


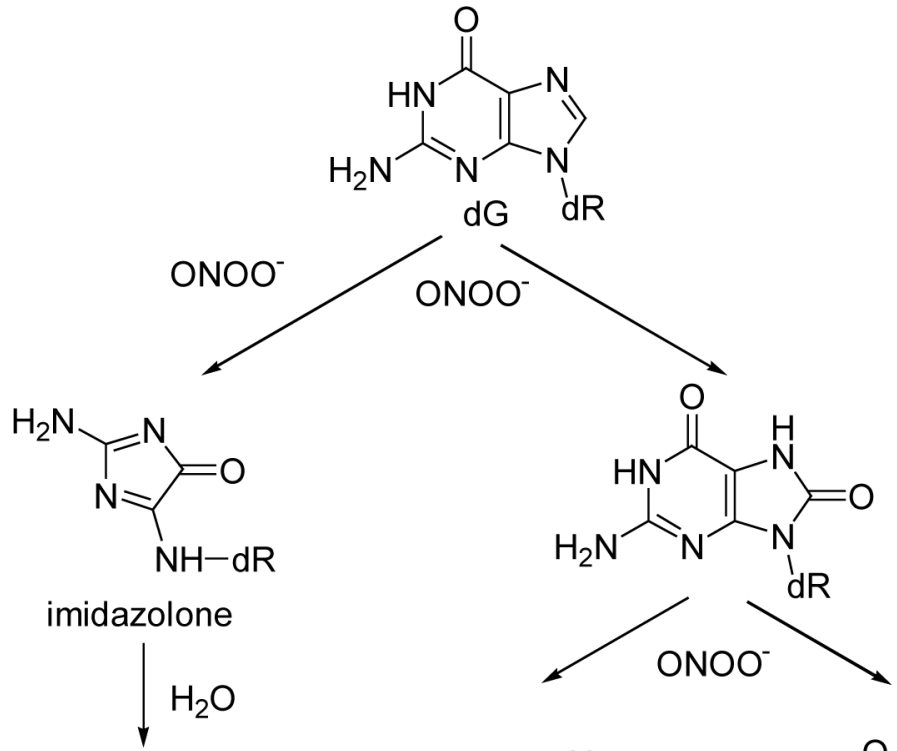<smiles>[R]ONC1=NC(N)(N)OC1=O</smiles>

oxazolone<smiles>[R]N1C(=O)NC(=O)C1NC(N)=O</smiles>

guanidinohydantoin<smiles>[R]N1C(=O)NC(=O)C12NC(N)=NC2=O</smiles>

spiroiminodihydantoin

Scheme 1.

Products of oxidation of $\mathrm{dG}$ by peroxynitrite 
<smiles>[R]N1C(=O)NC2(OO[N+](=O)[O-])C(=O)N=C(N)N=C12</smiles><smiles>[R]NC1=NC(N)(N)OC1=O</smiles><smiles>[R]N1C(=O)NC2(O)C(=O)N=C(N)N=C12</smiles><smiles>[R]N1C(=O)NC(=O)C1NC(N)=O</smiles><smiles>[R]N1C(=O)NC(=O)C12NC(N)=NC2=O</smiles>

guanidinohydantoin spiroiminodihydantoin

Scheme 2.

Secondary oxidation products of 8-oxodG 
Table 1

Yields of Spiroiminodihydantoin and 8-OxodG by Various Enzymatic Digestion Methods

\begin{tabular}{|c|c|c|c|}
\hline Enzvmes & DNA digestion vield & 8-oxodG $/ 10^{6}$ bases & Spiroiminodi-hvdantoin $/ 10^{6}$ bases \\
\hline NP1/acid phosphatase & $83 \pm 1.5 \%$ & $4 \pm 0.7$ & $10 \pm 0.4$ \\
\hline $\mathrm{NP} 1 / \mathrm{AP}(12 \mathrm{~h})$ & $87 \pm 0.3 \%$ & $15 \pm 1.8$ & $9 \pm 0.6$ \\
\hline NP1/AP (24h) & $90 \pm 1 \%$ & $15 \pm 2.0$ & $9 \pm 0.7$ \\
\hline phosphodiesterase I (5'-exo)/AP & $71 \pm 8 \%$ & $12 \pm 1.7$ & $8 \pm 0.8$ \\
\hline phohphodiesterase II (3'-exo)/AP & $36 \pm 4 \%$ & $14 \pm 1.9$ & $10.8 \pm 1.2$ \\
\hline
\end{tabular}

AP $=$ alkaline phosphatase, $\mathrm{NP} 1=$ nuclease $\mathrm{P} 1$ 